\title{
PANEL COINTEGRATION ANALYSIS OF CONSUMER CONFIDENCE AND PERSONAL CONSUMPTION IN THE EUROPEAN UNION
}

\author{
Sadullah Çelik ${ }^{1}$, Yasemin Özerkek ${ }^{2}$ \\ Marmara University, Department of Economics, Kuyubasi, Kadıköy, Istanbul, 34722, Turkey \\ E-mails: ${ }^{1}$ scelik@marmara.edu.tr; ${ }^{2}$ yasemin.ozerkek@marmara.edu.tr \\ Received 18 June 2008; accepted 20 February 2008
}

\begin{abstract}
This study examines the relationship between consumer confidence, personal consumption, and other relevant economic and financial variables for 9 European Union countries. It is argued that consumer confidence is an early indicator of future rates of growth in an economy through the consumption channel. Therefore, an increase in consumer confidence should translate into higher rates of consumption in the future, leading to a possible rise in economic growth. Our panel data analysis, conducting panel unit root tests and panel cointegration tests, tries to measure the effects of changes in consumer sentiment on personal consumption expenditures while accounting for other significant economic and financial variables such as stock exchange index, real exchange rates and interest rates. The empirical findings show the existence of a longrun relationship. Thus, consumers are able to detect early signals about future rates of economic growth as they contribute through the consumption channel.
\end{abstract}

Keywords: consumer confidence; personal consumption; panel cointegration.

JEL Classification: C33, D12, E21

\section{Introduction}

An issue having a sustained interest in macroeconomics is the analysis of consumer confidence. The concern in consumer attitudes stems from the idea that consumers' expectations of future economic sustainability (Tvaronavičienè et al. 2008; Grybaitè and Tvaronavičienè 2008) play an important role in macroeconomic results. Hence, in many countries consumer confidence indices (CCI) are constructed to measure consumer attitudes, thereby representing the potential impact of the psychological decision-making process of consumer in economics. Katona (1960) is credited as the leading figure on the concept and measurement of consumer confidence ${ }^{1}$.

The motivation for consumer confidence surveys is based on the discipline of psychological economics. This branch suggests that consumer expenditures depend not only on an ability to buy but also a willingness to buy (Katona 1968). Ability to buy refers to the objective factors that determine the expenditures of the consumer and includes financial resources such as consumer's income, available financial assets, and access to credit. Willingness to buy captures the subjective factor and depends mainly on attitudes and expectations about personal finances and the economy as a whole ${ }^{2}$. The general belief is that income is unable to include all the information that explains the changes in consumption. The consumer confidence index, a composition trying to measure both the ability and willingness to buy that individuals possess, might contain additional information in determination of consumption alongside other significant economic and financial variables.

This study examines the role of consumer sentiment on consumption expenditures by using advanced panel data analysis for 9 European Union countries. Section 2 includes a brief survey of the consumer confidence literature. Section 3 describes the methodology and presents empirical findings and the last section concludes with some remarks.

\section{Previous studies on consumer confidence}

Consumer confidence index, which measures the confidence of consumers about the state of the economy and their spending power, is considered a significant leading indicator in economics due to its earlier announcement compared to other indicators (variables) in the economy. 
Throop (1992) points out three different approaches to the analysis of consumer confidence:

i) First view argues that consumer confidence index is a measurement of uncertainty or risk which comprises the possibility of job and/or income loss. This is likely to be associated with the economic conditions but it impinges on consumer spending. As the probability of financial distress rises, an individual household saves more in liquid form to overcome a possible short fall in future income. The household individual puts off expenditures on consumer durables due to the illiquidity (Mishkin 1976, 1978; Berg and Bergstrom 1996). Hence, consumer confidence should measure confidence or distrust rather than optimism or pessimism.

ii) Second view argues that consumer confidence predominantly measures optimism or pessimism about future economic conditions. This view is related to the life cycle-permanent income hypothesis (LC-PIH), where current spending depends upon expected future income ${ }^{3}$. Consumers decide upon their current consumption by taking into consideration the total amount of disposable resources over their whole lifetime. Therefore, consumer confidence index may offer a better measure than the models relying on past income values ${ }^{4}$. Some of the studies in this category are Matsusaka and Sbordone (1995), Utaka (2003), and Afshar et al. (2007).

iii) The third view is the Rational Expectations Permanent Income Hypothesis (REPIH) which argues that consumer confidence is a significant forecaster of spending. Hence, in order to make accurate predictions of consumer spending, a survey of set of questions is essential. The most recent studies in this group are Garner (2002), Ludvigson (2004), Kwan and Cotsomitis $(2004,2006)$.

The second and third views are termed as the conventional approaches in consumer confidence literature ${ }^{5}$. Studies like Carroll et al. (1994) and Acemoğlu and Scott (1994) search for the forecasting ability of sentiment for changes in consumption so that additional information content of consumer confidence is validated. Their argument is based on the notion that improvements in consumer sentiment should stimulate consumption growth in the short run. Hence, these studies use the predictive power from regressions of the growth of various measures of household spending on lagged values of the index of consumer sentiment while controlling for other variables:

$$
\Delta \log \left(P C E_{t}\right)=\alpha_{0}+\sum_{i=1}^{n} \beta_{i} C C I_{t-i}+\gamma X_{t-1}+\varepsilon_{t},
$$

where $P C E_{t}$ denotes expenditures on personal consumption at time $\mathrm{t}^{6}, C C I_{t-i}$ shows various lags of consumer confidence, $X_{t-1}$ denotes a vector of other variables at time $(t-1)^{7}$. In general, it is assumed that if consumer confidence is high for some period of time, consumer expenditures will be high in the following periods. This should be true particularly for the purchase of durable goods, such as cars and appliances. Purchases of durable goods tend to be discretionary and can be postponed if the time for purchase is not favourable . $^{2}$

In this respect, Equation (1) is used to test the significance and information content of consumer confidence using panel data analysis for 9 European countries. We also control for other significant economic and fnancial variables that could have a role on household's consumption decisions.

\section{Methodology and empirical findings}

An issue having a recent surge of interest in econometrics is non-stationary panels with cross-section and time series dimensions. The analysis of panel data has particularly focused on unit root and cointegration properties of variables in an attempt to increase statistical power as the conventional unit root tests or cointegration tests have the low power problem for non-stationary data ${ }^{9}$. The panel unit root tests are classified as first generation ${ }^{10}$ (Levin et al. 2002; Breitung 2000; Im et al. 2003) and second generation (Pesaran 2007) ${ }^{11}$.

The results of the panel unit root tests for 9 European Union countries are in Table $1^{12}$. We fail to find a unit root in the levels of the variables for 5 out of 35 cases. Moreover, we have Pesaran's CIPS test showing the existence of a unit root for each variable. Hence, we strongly believe that our variables exhibit non-stationary characteristics ${ }^{13}$.

The existence of non-stationarity at the same integration order is the priority in order to implement cointegration analysis. Since not only non-stationarity but also same integration order in all variables are attained, we can employ panel cointegration tests of Pedroni (1999 and 2004), Larsson et al. (2001) and Westerlund (2007).

The results of panel cointegration tests are in Table 2. For Pedroni (1999), 5 out of 7 cointegration tests for both homogenous and heterogeneous trend cases result in the rejection of the null of no cointegration ${ }^{14}$. This is the first evidence of cointegration between our variables PCE, CCI, SE, and EXC. Then, Johansen's 
Table 1. Panel Unit Root Tests in Levels

\begin{tabular}{|c|c|c|c|c|c|c|}
\hline \multirow{3}{*}{ Variable } & \multirow{3}{*}{ Case } & \multicolumn{3}{|c|}{ First Generation } & \multirow{2}{*}{\multicolumn{2}{|c|}{ Second Generation }} \\
\hline & & \multicolumn{2}{|c|}{ Common unit root } & \multirow{2}{*}{$\begin{array}{c}\text { Individual unit root } \\
\text { IPS }\end{array}$} & & \\
\hline & & LLC & Breitung & & $\begin{array}{c}\text { Pesaran } \\
\text { CIPS }\end{array}$ & $\begin{array}{c}\text { Pesaran } \\
\text { CD }\end{array}$ \\
\hline \multirow{2}{*}{ PCE } & Constant & $\begin{array}{l}-5.281^{*} \\
(0.000)\end{array}$ & - & $\begin{array}{l}-0.385 \\
(0.350)\end{array}$ & -1.382 & $\begin{array}{c}7.64 \\
(0.11)\end{array}$ \\
\hline & Constant and Trend & $\begin{array}{l}-2.011^{*} \\
(0.022)\end{array}$ & $\begin{array}{c}1.158 \\
(0.876)\end{array}$ & $\begin{array}{c}2.072 \\
(0.981) \\
\end{array}$ & -1.841 & $\begin{array}{c}8.31 \\
(0.13) \\
\end{array}$ \\
\hline \multirow{2}{*}{ CCI } & Constant & $\begin{array}{c}0.072 \\
(0.529)\end{array}$ & - & $\begin{array}{l}-0.783 \\
(0.217)\end{array}$ & -2.154 & $\begin{array}{c}5.38 \\
(0.08)\end{array}$ \\
\hline & Constant and Trend & $\begin{array}{c}0.827 \\
(0.796)\end{array}$ & $\begin{array}{l}-1.219 \\
(0.111)\end{array}$ & $\begin{array}{c}0.339 \\
(0.633)\end{array}$ & -2.522 & $\begin{array}{c}5.56 \\
(0.08)\end{array}$ \\
\hline \multirow{2}{*}{ SE } & Constant & $\begin{array}{l}-0.941 \\
(0.173)\end{array}$ & - & $\begin{array}{l}-0.441 \\
(0.329)\end{array}$ & -1.172 & $\begin{array}{l}46.40 \\
(0.71)\end{array}$ \\
\hline & Constant and Trend & $\begin{array}{l}-0.698 \\
(0.242)\end{array}$ & $\begin{array}{c}-1.864^{*} \\
(0.031)\end{array}$ & $\begin{array}{c}1.312 \\
(0.905)\end{array}$ & -2.356 & $\begin{array}{l}46.71 \\
(0.71)\end{array}$ \\
\hline \multirow{2}{*}{ EXC } & Constant & $\begin{array}{l}-0.581 \\
(0.281)\end{array}$ & - & $\begin{array}{l}1.279 \\
(0.900)\end{array}$ & -2.311 & $\begin{array}{c}-0.43 \\
(-0.01)\end{array}$ \\
\hline & Constant and Trend & $\begin{array}{l}-0.407 \\
(0.342)\end{array}$ & $\begin{array}{l}-0.741 \\
(0.229) \\
\end{array}$ & $\begin{array}{c}0.818 \\
(0.793) \\
\end{array}$ & -2.808 & $\begin{array}{c}-0.66 \\
(-0.01) \\
\end{array}$ \\
\hline \multirow{2}{*}{ INT } & Constant & $\begin{array}{l}-2.884 * \\
(0.002)\end{array}$ & - & $\begin{array}{l}-2.283^{*} \\
(0.011)\end{array}$ & -2.847 & $\begin{array}{l}54.44 \\
(0.83)\end{array}$ \\
\hline & Constant and Trend & $\begin{array}{c}0.859 \\
(0.805)\end{array}$ & $\begin{array}{l}-0.638 \\
(0.262)\end{array}$ & $\begin{array}{l}-0.202 \\
(0.420)\end{array}$ & -2.743 & $\begin{array}{l}53.40 \\
(0.81)\end{array}$ \\
\hline
\end{tabular}

Modified Hannan-Quinn Information Criteria are chosen to specify the lag length for LLC, Breitung and IPS and Schwarz Information Criteria are used for Pesaran's CIPS. Maximum lag length is set to 9 for all tests. For CIPS test, the critical value with constant is -2.32 and with constant and trend is -2.83 at $5 \%$ significance level. The numbers in brackets are the p-values for all tests except $\mathrm{CD}$ where they are cross-section correlation coefficients of the residuals computed by the formula, $C D=$ $[T N(N-1) / 2]^{1 / 2} \rho .(*)$ denotes significance at $5 \%$ level.

(1988 and 1991) individual trace statistics are calculated for the cointegration equation of PCE, CCI, SE, EXC and $\mathrm{INT}^{15}$. France, Germany and Spain have one cointegrating vector, Italy and Netherlands show two cointegrating vectors and Ireland, Portugal and UK have none. After the trace statistics are averaged for all five ranks, the derived $\mathrm{Y}_{\mathrm{LR}}$ test of Larsson et al. (2001) signal the existence of three cointegrating vectors for the panel, strengthening our claim on a long-run relationship. Last, we employ Westerlund (2007) tests to check the existence of cointegration and we are able to reject the null of no cointegration for all cases. Hence, our empirical findings suggest the existence of panel cointegration between PCE, CCI and a group of control variables. Once panel cointegration is detected, it is important to obtain coefficient estimates for the variables in question. There are two well-known methods for coefficient estimation in cointegrated panels as FM-OLS developed by Pedroni (2000) and DOLS developed by Stock and Watson $(1993,2003)$.
In Table 3, FM-OLS and DOLS estimates of CCI, SE, EXC and INT are displayed for 9 European countries individually and for the panel group. In FM-OLS, we have statistical significance for all the variables except CCI for the case of UK. The sign of the coefficients are not in line with conventional economic theory for 4 countries in case of CCI, 2 in case of SE and 3 in cases of EXC and INT, respectively. The statistical significance for each country employing DOLS are slightly unsatisfactory than FM-OLS as we fail to reject the null of no cointegration for 3 countries in case of CCI and INT, 4 in case of SE and 2 in case of EXC. The signs of significant coefficients are against our a priori theoretical expectations for 1 country in CCI and EXC, none in SE, and 2 in INT. However, panel group estimates of FM-OLS and DOLS are all statistically significant and support theoretical propositions. A $1 \%$ increase in consumer sentiment (stock exchange indices) increases future rates of real personal consumption expenditures as much as $0.1(0.08) \%$ according to FM-OLS and $0.23(0.06) \%$ according to DOLS ${ }^{16}$. 
Table 2. Panel Cointegration Tests

\begin{tabular}{|c|c|c|c|c|c|}
\hline \multicolumn{3}{|c|}{ Pedroni (1999) } & \multirow{2}{*}{$\begin{array}{c}\text { Pedroni (2004) } \\
\text { Weighted } \\
\text { Statistic }\end{array}$} & & \\
\hline Test & $\begin{array}{c}\text { Homogenous } \\
\text { Trend }\end{array}$ & $\begin{array}{l}\text { Heterogenous } \\
\text { Trend }\end{array}$ & & & \\
\hline Panel v-statistic & -3.179 & -0.061 & $3.066^{*}$ & & \\
\hline Panel $\rho$-statistic & -0.497 & $-1.732 *$ & -1.167 & & \\
\hline Panel pp-statistic & $-1.949 *$ & $-2.238^{*}$ & $-1.942 *$ & & \\
\hline Panel adf-statistic & $-1.844 *$ & $-2.149 *$ & $-2.126^{*}$ & & \\
\hline Group p-statistic & $-4.281 *$ & -1.083 & & & \\
\hline Group pp-statistic & $-4.507^{*}$ & $-1.803^{*}$ & & & \\
\hline Group adf-statistic & $-4.899^{*}$ & $-2.044 *$ & & & \\
\hline \multicolumn{6}{|c|}{ Larsson et al. (2001) } \\
\hline COUNTRY - Trace Test & $r=\mathbf{0}$ & $r=1$ & $r=2$ & $r=\mathbf{3}$ & $r=4$ \\
\hline Denmark & 65.328 & 32.285 & 15.872 & 4.281 & 0.033 \\
\hline France & $74.110^{*}$ & 44.723 & 20.923 & 9.672 & 1.789 \\
\hline Germany & $78.730^{*}$ & 43.041 & 17.460 & 6.740 & 0.702 \\
\hline Ireland & 46.034 & 23.795 & 14.999 & 6.933 & 1.584 \\
\hline Italy & $126.568^{*}$ & 54.983* & 19.104 & 9.295 & 3.206 \\
\hline Netherlands & $87.992 *$ & $48.601 *$ & 25.683 & 11.027 & 2.860 \\
\hline Portugal & 60.729 & 35.426 & 18.894 & 9.017 & 1.936 \\
\hline Spain & $77.383^{*}$ & 37.726 & 13.502 & 4.458 & 0.395 \\
\hline United Kingdom & 62.046 & 40.553 & 23.376 & 7.510 & 2.632 \\
\hline $5 \%$ Critical Value & 69.819 & 47.856 & 29.797 & 15.495 & 3.841 \\
\hline$Y_{L R}$ test & $11.031 *$ & $5.528 *$ & $2.361 *$ & 1.454 & 1.099 \\
\hline \multicolumn{6}{|c|}{ Westerlund (2007) } \\
\hline Test & Constant & $\begin{array}{c}\text { Constant and } \\
\text { Trend } \\
\end{array}$ & & & \\
\hline $\mathbf{G}_{\boldsymbol{\tau}}$ & $-13.055^{*}$ & $-12.642 *$ & & & \\
\hline $\mathbf{G a}$ & $-83.907^{*}$ & $-74.802^{*}$ & & & \\
\hline $\mathbf{P}_{\tau}$ & $-9.979 *$ & $-9.304^{*}$ & & & \\
\hline $\mathbf{P}_{\alpha}$ & $-81.889^{*}$ & $-69.654 *$ & & & \\
\hline
\end{tabular}

For Pedroni (1999 and 2004), except for panel v-statistic, and for Westerlund (2007) all statistics have -1.645 as $5 \%$ critical value. The critical value of v-statistic is 1.645 at $5 \%$ level. For Larsson et al. (2001) trace test includes a constant and the lag length is determined by SIC. For all three tests, $(*)$ denotes rejection of the null at $5 \%$ significance level.

Moreover, an increase in real effective exchange rate leads to a rise in imports which probably stimulates domestic consumption. On the other hand, an increase in interest rates increases the cost of borrowing which in turn leads to a fall in consumption. It is also important to note that EXC and INT have more than one-to-one relationship with the personal consumption expenditures in both FM-OLS and DOLS. These findings clearly demonstrate the importance of consumer confidence as a determinant of personal consumption while boosting its role as a leading economic indicator.

\section{Conclusions}

Consumer confidence indices have long been used as congruent indicators of economic activity in developed countries. That is why economic agents and market players, as well as the professionals of the sector closely follow their regular announcement. If an economy has a significant aggregate propensity to consume, then consumer confidence is expected to affect/be affected by aggregate demand, financial variables and expectations. 
Table 3. FM-OLS and DOLS Tests for Coefficient Estimations

\begin{tabular}{|c|c|c|c|c|c|c|c|c|}
\hline \multirow[b]{2}{*}{ COUNTRY } & \multicolumn{4}{|c|}{ FM-OLS } & \multicolumn{4}{|c|}{ DOLS } \\
\hline & CCI & $\mathbf{S E}$ & EXC & INT & CCI & $\mathbf{S E}$ & EXC & INT \\
\hline Denmark & $\begin{array}{c}0.46^{*} \\
(-4.89)\end{array}$ & $\begin{array}{c}0.05^{*} \\
(-47.30)\end{array}$ & $\begin{array}{l}-0.70^{*} \\
(-3.44)\end{array}$ & $\begin{array}{c}-1.95^{*} \\
(-14.22)\end{array}$ & $\begin{array}{l}0.58^{*} \\
(5.61)\end{array}$ & $\begin{array}{l}0.03 * \\
(2.08)\end{array}$ & $\begin{array}{c}-0.19 \\
(-0.49)\end{array}$ & $\begin{array}{l}-2.17^{*} \\
(-16.28)\end{array}$ \\
\hline France & $\begin{array}{c}-0.02 * \\
(-11.44)\end{array}$ & $\begin{array}{c}0.07 * \\
(-30.75)\end{array}$ & $\begin{array}{c}-5.85^{*} \\
(-11.18)\end{array}$ & $\begin{array}{l}-2.01 * \\
(-9.90)\end{array}$ & $\begin{array}{c}0.11 \\
(1.02)\end{array}$ & $\begin{array}{l}0.07 * \\
(2.14)\end{array}$ & $\begin{array}{c}-6.89^{*} \\
(-11.42)\end{array}$ & $\begin{array}{l}-1.91^{*} \\
(-9.39)\end{array}$ \\
\hline Germany & $\begin{array}{c}0.13 * \\
(-29.94)\end{array}$ & $\begin{array}{c}-0.02 * \\
(-107.30)\end{array}$ & $\begin{array}{l}1.44 * \\
(5.03)\end{array}$ & $\begin{array}{c}0.25^{*} \\
(-6.21)\end{array}$ & $\begin{array}{l}0.10^{*} \\
(2.65)\end{array}$ & $\begin{array}{l}-0.01 \\
(-0.59)\end{array}$ & $\begin{array}{c}1.47^{*} \\
(17.18)\end{array}$ & $\begin{array}{l}0.31 * \\
(2.72)\end{array}$ \\
\hline Ireland & $\begin{array}{c}-0.41 * \\
(-11.75)\end{array}$ & $\begin{array}{c}0.33 * \\
(-13.33)\end{array}$ & $\begin{array}{l}2.20 * \\
(3.59)\end{array}$ & $\begin{array}{l}-0.79^{*} \\
(-3.02)\end{array}$ & $\begin{array}{l}-0.27^{*} \\
(-2.48)\end{array}$ & $\begin{array}{l}0.26^{*} \\
(5.37)\end{array}$ & $\begin{array}{l}2.62 * \\
(8.57)\end{array}$ & $\begin{array}{l}-0.67 \\
(-1.52)\end{array}$ \\
\hline Italy & $\begin{array}{c}0.10^{*} \\
(-12.64)\end{array}$ & $\begin{array}{c}0.02 * \\
(-54.67)\end{array}$ & $\begin{array}{l}5.57 * \\
(9.14)\end{array}$ & $\begin{array}{c}0.25^{*} \\
(-2.87)\end{array}$ & $\begin{array}{l}0.13 * \\
(2.20)\end{array}$ & $\begin{array}{c}0.01 \\
(1.46)\end{array}$ & $\begin{array}{c}5.95^{*} \\
(20.06)\end{array}$ & $\begin{array}{l}0.37 * \\
(2.18)\end{array}$ \\
\hline Netherlands & $\begin{array}{c}-0.05^{*} \\
(-20.67)\end{array}$ & $\begin{array}{c}0.13^{*} \\
(-51.51)\end{array}$ & $\begin{array}{l}2.69 * \\
(8.44)\end{array}$ & $\begin{array}{l}-0.38^{*} \\
(-7.08)\end{array}$ & $\begin{array}{c}0.05 \\
(0.88)\end{array}$ & $\begin{array}{l}0.13 * \\
(6.87)\end{array}$ & $\begin{array}{c}3.23 * \\
(14.45)\end{array}$ & $\begin{array}{c}-0.23 \\
(-1.59)\end{array}$ \\
\hline Portugal & $\begin{array}{c}0.26^{*} \\
(-6.16)\end{array}$ & $\begin{array}{c}0.12 * \\
(-44.10)\end{array}$ & $\begin{array}{l}3.53 * \\
(9.30)\end{array}$ & $\begin{array}{l}-0.02^{*} \\
(-4.18)\end{array}$ & $\begin{array}{l}0.28 * \\
(2.03)\end{array}$ & $\begin{array}{l}0.12 * \\
(5.28)\end{array}$ & $\begin{array}{c}3.59^{*} \\
(13.65)\end{array}$ & $\begin{array}{c}0.05 \\
(0.23)\end{array}$ \\
\hline Spain & $\begin{array}{c}-0.04 * \\
(-19.60)\end{array}$ & $\begin{array}{c}0.06^{*} \\
(-41.17)\end{array}$ & $\begin{array}{c}3.50^{*} \\
(10.07)\end{array}$ & $\begin{array}{c}0.02 * \\
(-3.83)\end{array}$ & $\begin{array}{c}0.05 \\
(0.77)\end{array}$ & $\begin{array}{c}0.02 \\
(0.61)\end{array}$ & $\begin{array}{c}3.91 * \\
(14.38)\end{array}$ & $\begin{array}{l}-0.08 \\
(-0.37)\end{array}$ \\
\hline United Kingdom & $\begin{array}{c}0.46 \\
(-1.60)\end{array}$ & $\begin{array}{c}-0.05^{*} \\
(-13.64)\end{array}$ & $\begin{array}{l}-0.52 * \\
(-6.78)\end{array}$ & $\begin{array}{l}-5.00^{*} \\
(-7.71)\end{array}$ & $\begin{array}{l}1.02 * \\
(2.15)\end{array}$ & $\begin{array}{l}-0.09 \\
(-1.01)\end{array}$ & $\begin{array}{c}-0.37 \\
(-1.15)\end{array}$ & $\begin{array}{l}-6.26^{*} \\
(-5.63)\end{array}$ \\
\hline Panel Group & $\begin{array}{c}0.10^{*} \\
(-39.56)\end{array}$ & $\begin{array}{c}0.08^{*} \\
(-134.59)\end{array}$ & $\begin{array}{l}1.32 * \\
(8.06)\end{array}$ & $\begin{array}{c}-1.07^{*} \\
(-19.67)\end{array}$ & $\begin{array}{l}0.23 * \\
(4.94)\end{array}$ & $\begin{array}{l}\text { 0.06* } \\
(7.40)\end{array}$ & $\begin{array}{l}1.48^{*} \\
(25.07)\end{array}$ & $\begin{array}{l}-1.18^{*} \\
(-9.88)\end{array}$ \\
\hline
\end{tabular}

The values in the brackets are the t-ratios. Maximum lag length is set to 3 according to SIC. In both tests, only a constant is included. $(*)$ denotes significance at $5 \%$ level.

This study investigates the effects of changes in consumer confidence, along with other significant variables, on the personal consumption expenditures utilizing data for nine European Union countries with rigorous panel analysis. The empirical results show that there exists a long-run relationship between consumer confidence index, stock exchange index, real exchange rates, interest rates, and personal consumption expenditures.

To sum up, European consumer confidence indices are very functional leading indicators. In this respect, we are able to detect their strong relationship with significant financial variables. Thus, as a preliminary inference, we have support for the sensitivity of consumers in their decisions about the future of the economy as they make the best use of available information on economic and financial variables, and expectations.

\section{Endnotes}

1 In order to evaluate, fathom, and analyse the impact of changes in consumer attitudes and expectations, the first survey of consumer confidence was conducted in the United States by University of Michigan in the 1940s.

2 A recent study by Roos (2008) shows that Katona's theory of psychological analysis of economic behaviour can be incorporated into the standard model of intertemporal utility maximization by allowing for a time-varying preference parameter which is exogenous to the consumer and determined by the social environment.

3 Modigliani and Brumberg (1954) have developed the life-cycle theory, and Friedman (1957) has introduced the permanent-income hypothesis. Hall (1978) shows that under the permanent income hypothesis, consumption could have high inertia close to a random walk.

4 Campbell and Mankiw (1991) separate the consumption behaviour of households into two parts as those individuals who follow the permanent income hypothesis and those who simply consume their current income. 
5 Pascal (2006) offers a recent survey of the consumer confidence literature.

6 Consumption is defined as the real personal consumption expenditures.

7 The choice of variables is somewhat arbitrary. Carroll et al. (1994) employ lags of the growth of real labour income and the lags of the dependent variable. Fan and Wong (1998) use median income for Hong Kong.

8 Van Oest and Franses (2008) caution that changes in consumer confidence should be interpreted with care as the same individuals are not surveyed over time..

9 See Breitung and Pesaran (2008) for an excellent review of the literature on panel unit root and panel cointegration tests.

${ }^{10}$ These first generation panel unit root tests ignore cross-sectional dependence. There are other first generation tests such as Hadri (2000), Fisher-ADF and Fisher-PP tests developed by Maddala and $\mathrm{Wu}(1999)$ and Choi (2001) utilizing Fisher (1932) results. We obtained similar results when we applied them and do not report here to save space.

${ }^{11}$ Pesaran (2007) is based on single common factor with correlation coefficients for cross-sectional dependency. There are other second generation tests such as Phillips and Sul (2003), Bai and $\mathrm{Ng}$ (2004), and Moon and Perron (2004). Gengenbach et al. (2006) show that Pesaran's CIPS and CADF statistics exhibit powerful properties.

${ }^{12}$ The data, definitions of the variables and resources are in Appendix.

13 The first differences of panel unit root tests show stationarity for all variables. The results are available from the authors upon request.

${ }^{14}$ We omit INT from control variables due to insignificant results.

${ }^{15}$ We add INT as a control variable to check the existence of cointegration.

${ }^{16}$ Jansen and Nahuis (2003) show similar results for 11 European countries while examining the relationship between consumer confidence and stock market.

\section{References}

Acemoğlu, D. and Scott, A. 1994. Consumer confidence and rational expectations: Are agents beliefs consistent with the theory? Economic Journal 104(422): 1-19.

Afshar, T.; Arabian, G.; Zomorrodian, R. 2007. Stock return, consumer confidence, purchasing manager's index and economic fluctuations, Journal of Business and Economics Research 5(8): 97-106.

Bai, J. and Ng, S. 2004. A panic attack on unit roots and cointegration, Econometrica 72(4): 1127-1177.

Berg, L. and Bergstrom, R. 1996. Consumer confidence and consumption in Sweden. Working Paper No.7. Department of Economics, Uppsala University.

Breitung, J. 2000. The local power of some unit root tests for panel data, in Baltagi, B. (Ed.). Nonstationary Panels, Panel Cointegration, and Dynamic Panels, Advances in Econometrics, Amsterdam: JAI Press, 161-178.

Breitung, J. and Pesaran, M. H. 2008. Unit roots and cointegration in panels, in Matyas, L. and Sevestre, P. (Eds.). The Econometrics of Panel Data: Fundamentals and Recent
Developments in Theory and Practice, Kluwer Academic Publishers, 279-322.

Campbell, J. Y. and Mankiw, N.G. 1991. The response of consumption to income - a cross-country investigation, $E u$ ropean Economic Review 35(4): 723-756.

Carroll, C. D.; Fuhrer, J. C.; Wilcox, D. W. 1994. Does consumer sentiment forecast household spending? If so, why? American Economic Review 84(5): 1397-1408.

Choi, I. 2001. Unit root tests for panel data, Journal of International Money and Finance 20(2): 249-272.

Fan, C. S. and Wong, P. 1998. Does consumer sentiment forecast household spending? The Hong Kong Case, Economics Letters 58(1): 77-84.

Fisher, R. A. 1932. Statistical methods for research workers. Oliver and Boyd: Edinburgh.

Friedman, M. 1957. A theory of the consumption function. Princeton: Princeton University Press.

Garner, A. 2002. Consumer confidence after September 11, Economic Review 87(2): 5-25.

Gengenbach, C.; Palm, F. C.; Urbain, J.P. 2006. Panel unit root tests in the presence of cross-sectional dependencies: comparison and implications for modeling. METEOR, Maastricht Research School of Economics of Technology and Organization.

Grybaitè, V.; Tvaronavičienè, M. 2008. Estimation of sustainable development: germination on institutional level, Journal of Business Economics and Management (9)4: 327-335.

Hadri, K. 2000. Testing for stationarity in heterogeneous panel data, Econometrics Journal 3(2): 148-161.

Hall, R. E. 1978. Stochastic implications of the life cyclepermanent income hypothesis: theory and evidence, Journal of Political Economy 86(6): 971-987.

Im, K. S.; Pesaran, M. H.; Shin, Y. 2003. Testing for unit roots in heterogeneous panels, Journal of Econometrics 115(1): 53-74.

Jansen, W. J. and Nahuis, N. J. 2003. The stock market and consumer confidence: European evidence, Economics Letters 79(1): 89-98.

Johansen, S. 1988. Statistical analysis of cointegration vectors, Journal of Economic Dynamics and Control 12(2-3): 231-54.

Johansen, S. 1991. Estimation and hypothesis testing of cointegration vectors in Gaussian vector autoregressive models, Econometrica 59(6): 1551-1580.

Katona, G. 1960. The powerful consumer. New York: McGraw Hill.

Katona, G. 1968. Consumer behavior: Theory and findings on expectations and aspirations, The American Economic Review 58(2): 19-30.

Kwan, A. C. C. and Cotsomitis, J. A. 2004. Can consumer attitudes forecast household spending in United States? Further evidence from the Michigan surveys of consumers, Southern Economic Journal 71(1): 136-144. 
Kwan A. C. C. and Cotsomitis, J. A. 2006. The usefulness of consumer confidence in forecasting household spending in Canada: A national and regional analysis, Economic Inquiry 44(1): 185-197.

Larsson, R.; Lyhagen, J.; Löthgren, M. 2001. Likelihoodbased cointegration tests in heterogeneous panels, Econometrics Journal 4(1): 109-142.

Levin, A.; Lin, C.; Chu, J. J. 2002. Unit root test in panel data: Asymptotic and finite sample properties, Journal of Econometrics 108(1): 1-24.

Ludvigson, S. C. 2004. Consumer confidence and consumer spending, Journal of Economic Perspectives 18(2): 29-50.

Maddala, G. S. and Wu, S. 1999. A comparative study of unit root tests with panel data and a new simple test, Oxford Bulletin of Economics and Statistics 61(1): 631-652.

Matsusaka, J. G. and Sbordone, A. 1995. Consumer confidence and economic fluctuations, Economic Inquiry 33(2): 296-318.

Mishkin, F. S. 1976. Illiquidity, consumer durable expenditure, and monetary policy, American Economic Review 66(4): 642-654.

Mishkin, F. S. 1978. Consumer sentiment and spending on durable goods, Brookings Papers on Economic Activity 1: 217-232.

Modigliani, F. and Brumberg, R. E. 1954. Utility analysis and the consumption function: an interpretation of crosssection data, in Kurihara, K. K. (Ed.). Post-Keynesian Economics. New Brunswick, N. J.: Rutgers University Press.

Moon, H. R. and Perron, B. 2004. Testing for a unit root in panels with dynamic factors, Journal of Econometrics 122(1): 81-126.

Pascal, D. 2006. Does consumer confidence forecast household spending? MPRA Paper No. 902, November.

Pedroni, P. 1999. Critical values for cointegration tests in heterogeneous panels with multiple regressors, Oxford Bulletin of Economics and Statistics 61(1): 653-670.
Pedroni, P. 2000. Fully modified OLS for heterogeneous cointegrated panels, in Baltagi, B. (Ed.). Nonstationary Panels, Panel Cointegration, and Dynamic Panels, Advances in Econometrics. Amsterdam: JAI Press, 93-130.

Pedroni, P. 2004. Panel cointegration: asymptotic and finite sample properties of pooled time series tests with an application to the PPP hypothesis, Econometric Theory 3: 579-625.

Pesaran, M.H. 2007. A simple panel unit root test in the presence of cross section dependence, Journal of Applied Econometrics 22(2): 265-312.

Phillips, P. C. B. and Sul, D. 2003. Dynamic panel estimation and homogeneity testing under cross section dependence, Econometrics Journal 6(1): 217-259.

Roos, M. W. M. 2008. Willingness to consume and ability to consume, Journal of Economic Behavior and Organization 66(2): 387-402.

Stock, J. H. and Watson, M. W. 1993. A simple estimator of cointegrating vectors in higher order integrated systems, Econometrica 61(4): 783-820.

Stock, J. H. and Watson, M. W. 2003. Introduction to econometrics. Addison Wesley.

Throop, A. W. 1992. Consumer sentiment: Its causes and effects, Federal Reserve Bank of San Francisco Economic Review 1: 35-59.

Tvaronavičienė, M.; Grybaitė, V.; Tvaronavičius, V. 2008. Economic and other development aspects of Baltic countries: estimation issues, in $5^{\text {th }}$ International Scientific Conference: 'Business and Management' 2008. Selected papers. Vilnius, Lithuania, May 16-17, 107-115. ISBN 978-9955-311-9.

Utaka, A. 2003. Confidence and the real economy: the Japanese case, Applied Economics 35(3): 337-342.

Van Oest, R. and Franses, P. H. 2008. Measuring changes in consumer confidence, Journal of Economic Psychology 29(3): 255-275.

Westerlund, J. 2007. Testing for error correction in panel data, Oxford Bulletin of Economics and Statistics 69(6): 709-748. 


\section{Appendix: Data definitions and sources}

The countries used are Denmark, France, Germany, Ireland, Italy, Netherlands, Portugal, Spain, and United Kingdom. The panel is balanced and covers 1997 January - 2006 December. The variables are personal consumption expenditures (PCE), consumer confidence index (CCI), stock exchange index (SE), real effective exchange rate (EXC) and long-run interest rate (INT). PCE, CCI, EXC and INT are obtained from Eurostat website. We use interpolation to convert PCE from quarterly values to monthly values by quadratic match sum method. The SE is the monthly closing values of stock exchange, and for Germany (DAX30), France (CAC40), Netherlands (AEX General) and UK (FTSE100) are collected from Yahoo Finance website, for Denmark (KFX) and Spain (IBEX35), from EconStats website, for Ireland (ISEQ) from Irish Stock Exchange, for Italy (MIB30) from Banco Di Brescia, and for Portugal (PSI20) from NYSE Euronext. We use CPI to deflate PCE and all variables are in their natural logarithms except interest rates. 